\title{
Obituary for a Political Geographer - Mangal Siddhi Manandhar, 1941 - 2016
}

Mangal Siddhi Manandhar was born on May 11, 1941 in Jhochhen Layakusa, Kathmandu, Nepal. He died on July 1, 2016 at the age of 75 . He did his first Master's degree in Geography from Tribhuvan University, Nepal in 1964 and also from the University of Kansas, Lawrence, the USA in 1969. He also did PhD from the University of Oklahoma, USA in 1973. He was honored by "Mahendra Bidhya Bhusan" for his Geography Master's degree in 1964 and for $\mathrm{PhD}$ in 1974, and Educational Medal in 1986. He joined the Central Department of Geography (CDG), Tribhuvan University

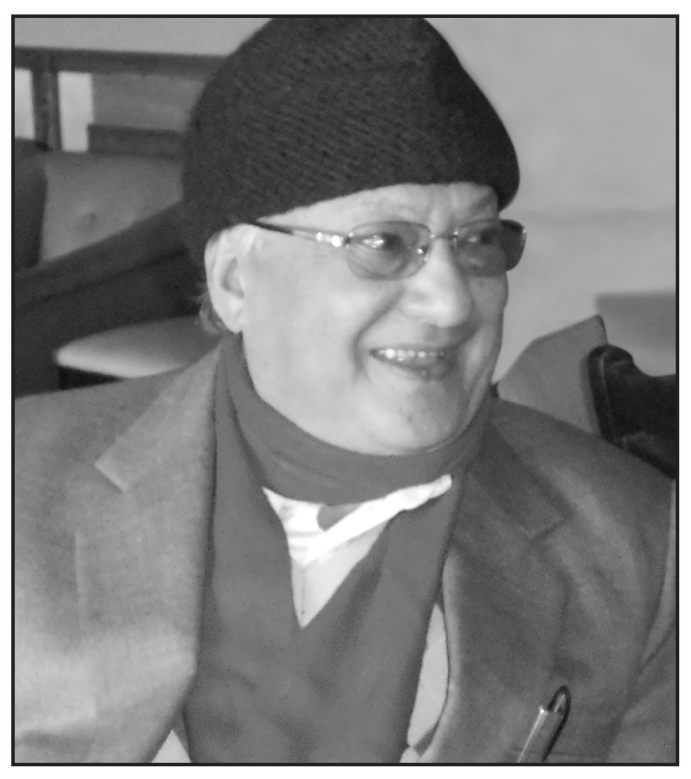
(TU) in 1973 as a Lecturer and promoted to Professor in 1980. Late Prof. Manandhar had multi-dimensional personality.

\section{A competent academic}

Late Prof. Manandhar with over 35 years of teaching and research experience was one of the energetic, ebullient and delightful geographers at the CDG, TU. He had more than 40 publications including articles in journals, books and newspapers. In addition, he had written more than 12 mimeographs. He had contributed papers in several national and international level seminars and conferences. He had served as chief editor for the Himalayan Review, the Journal of Nepal Geographical Society (1975-1985) and editor of the CDG's Geographical Journal of Nepal (1979-1999). He also served as Member Secretary of the Nepal Social Science Research Council since 1981. He was the member of TU Senate, the apex body of Tribhuvan University, which is responsible to direct and 
approve academic programs for TU. During his tenure in the CDG, he had led more than 36 research projects in different fields - environment, land use, settlement and market towns, hazard mapping, etc.

\section{A receptive academic administrator}

Late Prof. Manandhar had served as the Head of the Central Department of Geography, TU from 1987 to 1999. During his headship of the CDG, late Prof. Manandhar introduced recently emerging concepts, methods, and tools in the curricula of geography in higher education. He had introduced courses such as Geographic Information System (GIS) and Remote Sensing (RS) and other courses like mountain geography and applied geomorphology in the master's level curricula. With the support of National Planning Commission, Government of Nepal and UNEP-GRID, Bangkok/International Centre for Integrated Mountain Development (ICIMOD), the GIS/RS laboratory with wellequipped facilities had been set up in the CDG under his headship. He had been successful to generate financial resources for CDG through carrying out research and training activities. A series of training programs on GIS and RS for academics, academicians, policy makers, planners, technicians, and administrators working in the universities, government, non-government, and private organizations were organized during his CDG's headship. He had also tried to develop and strengthen relationships with different INGOs, NGOs, GOs and foreign universities for collaborative works.

\section{A benevolent planner and decision maker}

Late Prof. Manandhar had served the National Planning Commission of Nepal as ViceChairperson twice:once in 1994-95 and then again during April-October 1997. He had led the group involved in formulating the concept paper of the Ninth Plan for the country. Under his leadership as the Vice-Chairperson of the National Planning Commission he was instrumental to introduce some of the benevolent programs such as i) old-age allowances; ii) Aphno Gaun AphaiBanau (Let's Build Own Village by Ourself); and iii) capacity building of local bodies by making provision of lump sum financial grant to each Village Development Committee and local participatory approach across the country.

\section{A bold academic and political leader}

Late Prof. Manandhar had a quality of abled leadership. During his college time, he became General Secretary of the Student Union of Tri-Chandra College (1961-1962) 
and also Executive Member of the Student Union of the Kirtipur Central Campus, TU from 1962 to1964. He served as the President of International Club of Oklahoma University, USA in 1970. He also became the President of Teachers' Association of Kirtipur Campus during 1981-1983 and Nepal University Teachers' Association during 1983-1985.

At the end of 1999, he got to be elected as the parliamentary member from Kathmandu-5 constituency representing the CPN (UML) party. He served as the Minister of Education and Sport in the transitional government formed during the years 2005-06 upon ending of historical people revolution.

The Central Department of Geography has indeed lost Prof. Mangal Siddhi Manandhar, a prominent geographer who was highly committed to the development, and strengthening of geography education and research. The noteworthy memories of sincerity, frankness and friendliness he has left for us are unforgettable to follow. The department family members (CDG) extend their deepest condolence to his family. 